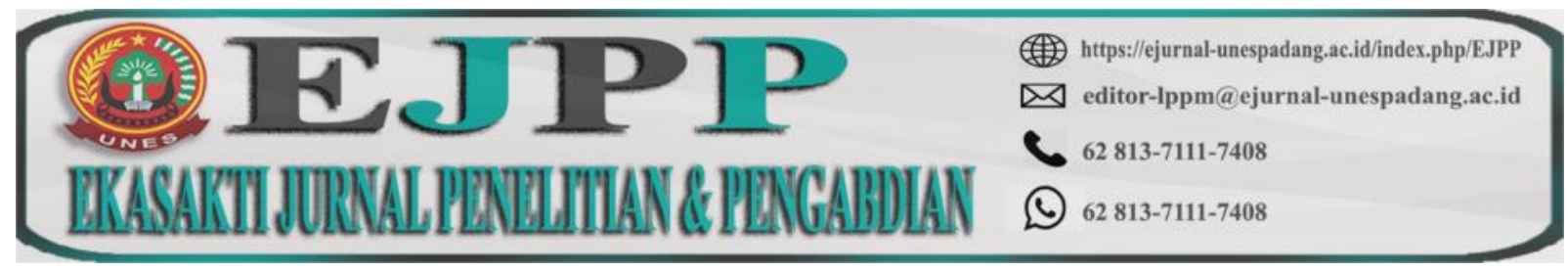

DOI: https://doi.org/10.31933/ejpp.v1i1

Received: 02/10/2020, Revised: 25/10/2020, Publish: 22/11/2020

\title{
PERAN ISOLAT RHIZOBAKTERIA DAN ZAT PENGHAMBAT TUMBUH DALAM PEMBENTUKAN DAN PERTUMBUHAN AKAR TANAMAN KENTANG
}

\author{
Henny Puspita Sari1, Warnita2, dan Indra Dwipa3 \\ 1) Program studi Agroteknologi Universitas Ekasakti Padang \\ Email: hpssp.henny@gmail.com \\ 2) Jurusan Budidaya Pertanian, Fakultas Pertanian, Universitas Andalas Kampus \\ Limau Manis, Padang \\ E-mail:warnita_irnu@yahoo.com \\ 3) Jurusan Budidaya Pertanian, Fakultas Pertanian, Universitas Andalas Kampus \\ Limau Manis, Padang \\ E-mail: 1965indradwipa@gmail.com
}

\begin{abstract}
ABSTRAK
PGPR adalah bakteri hidup bebas yang berada di tanah. Mereka baik secara langsung atau tidak langsung membantu perakaran. Akar merupakan organ yang sangat penting bagi tanaman, peran akar yang paling utama yaitu dalam pertumbuhan dan perkembangan tanaman. Tujuan untuk mendapatkan interaksi isolat rizobakteria dengan konsentrasi zat penghambat tumbuh coumarin dalam meningkatkan pembentukan umbi dan pertumbuhan tanaman kentang, serta mendapatkan isolat rhizobakteria dan konsentrasi pemberian coumarin yang terbaik dalam pertumbuhan dan pembentukan umbi tanaman kentang.

Penelitian ini mengunakan pola faktorial dalam rancangan acak lengkap dari dua faktor dengan tiga ulangan. Faktor pertama adalah isolat rhizobakteria yaitu tanpa isolat, isolat BT.4.1, isolat BT.4.2, isolat BT.4.3 dan faktor kedua adalah konsentrasi zat penghambat tumbuh coumarin, yaitu konsentrasi coumarin 0, 50, 100 dan $150 \mathrm{mg} / \mathrm{l}$.

Hasil penelitian menunjukan bahwa interaksi pemberian isolat rhizobakteria dan coumarin dapat menekan panjang akar tanaman kentang diperoleh pada isolat BT.4.1 dengan konsentrasi coumarin $50 \mathrm{mg}{ }^{1}$, sehingga energi yang digunakan bisa untuk pembentukan biji. Sedangkan pemberian coumarin secara tunggal tidak mempengaruhi, tetapi coumarin dapat menekan panjangan akar dan bobot basah akar.
\end{abstract}

Keywords: Coumarin, Isolat, Rhizobakteria, Tanaman kentang, Pertumbuhan. 


\begin{abstract}
PGPR is a free-living bacteria that resides in the soil. They either directly or indirectly assist rooting. Roots are very important organs for plants, the most important role of roots is in plant growth and development. The aim was to get the interaction of rhizobacteria isolates with the concentration of growth inhibitor coumarin in increasing tuber formation and potato plant growth, as well as to obtain the best rhizobacteria isolates and the best concentration of coumarin in the growth and formation of potato tubers.

This study used a factorial pattern in a completely randomized design of two factors with three replications. The first factor was rhizobacteria isolates, namely without isolates, BT.4.1 isolates, BT.4.2 isolates, BT.4.3 isolates and the second factor was the concentration of coumarin growth inhibitors, namely coumarin concentrations of $0,50,100$ and $150 \mathrm{mg} / \mathrm{l}$.

The results showed that the interaction between giving rhizobacteria and coumarin isolates could suppress the root length of potato plants obtained in BT.4.1 isolates with a coumarin concentration of $50 \mathrm{mg} \mathrm{l}^{-1}$, so that the energy used could be used for seed formation. While coumarin alone did not affect it, but coumarin could suppress root length and root wet weight.
\end{abstract}

Keywords: Coumarin, Isolates, Rhizobacteria, Potatoes, Growth.

\title{
PENDAHULUAN
}

Pupuk kimia pada umumnya digunakan untuk pasokkan nutrisi bagi tanaman. Namun, harga, ketersediaan, dan masalah lingkungan dari pupuk kimia menjadi masalah nyata bagi pertanian saat ini. Menurut Majeed, Kaleem Abbasi, Hameed, Imran, \& Rahim (2015) penerapan pupuk kimia dalam lanskap miring di bawah curah hujan tahunan yang tinggi biasanya tidak efektif, karena permukaan run off dan pencucian. Oleh karena itu, ada kebutuhan mendesak untuk menemukan strategi alternatif yang dapat memastikan hasil panen yang kompetitif, memberikan keamanan lingkungan, dan perlindungan serta mempertahankan keseimbangan ekologis jangka panjang dalam agroekosistem. Penggunaan inokulan mikroba atau rhizobateria pemacu pertumbuhan tanaman (PGPR) untuk peningkatan produksi pertanian berkelanjutan menjadi praktik yang lebih banyak diterima dalam pertanian.

Banyak produk mikroba digunakan untuk pertanian organik, dan pertanian komersial berskala besar di Cina, Amerika Serikat, dan Eropa mulai mengadopsi bahan biologis sebagai pengganti pupuk kimia dan pestisida (Parnell et al. 2016), yang sangat penting untuk pertanian keberlanjutan (Kecskés et al. 2016).

PGPR adalah bakteri hidup bebas yang berada di tanah. Mereka baik secara langsung atau tidak langsung membantu perakaran (Kumar and Sharma 2017). Akar merupakan organ yang sangat penting bagi tanaman, peran akar yang paling utama yaitu dalam pertumbuhan dan perkembangan tanaman. Akar tidak hanya menyediakan air dan nutrisi, tetapi juga memberikan dukungan mekanis dari mulai pembibitan dan pengembangan, menyediakan hormon pertumbuhan ke tanaman, meningkatkan kandungan bahan organik tanah, yang berfungsi untuk meningkatkan sifat fisik, kimia, dan biologis tanah, menghasilkan hasil panen yang lebih tinggi. 
Pertumbuhan awal akar yang kuat telah terbukti menjadi faktor utama dalam meningkatkan serapan N dalam gandum (Noulas et al. 2010). Sistem akar yang lebih besar memberikan kontak akar dan tanah yang lebih besar, yang sangat penting untuk penyerapan $\mathrm{P}$ (Gahoonia dan Nielsen, 2004), sedangkan untuk nutrisi yang kurang bergerak, seperti $\mathrm{P}$ dan $\mathrm{K}$, deplesi seringkali berkaitan erat dengan panjang akar (Fageria. N. K, 2013).

Akar berkolonisasi di rhizosphere dan melindungi tanaman dari patogennya, menghasilkan metabolit sekunder seperti santibiotik yang menekan rhizobacteria yang berbahaya, menghasilkan siderofor, dan phytohormones, dapat memperbaiki nitrogen atmosfer, dan membantu menyediakan penyerapan nutrisi dengan melarutkan fosfat dan menghasilkan zat aktif biologis yang memengaruhi pertumbuhan dan perkembangan tanaman (Kumar and Sharma 2017)

Menariknya, tanaman yang kekurangan fosfat melepaskan metabolit ke dalam rhizosfer yang juga muncul selama kondisi kekurangan zat besi (Ziegler et al. 2016). Tanaman menanggapi perubahan dalam lingkungan biotik atau abiotik mereka menunjukkan perubahan eksudasi akar (Carvalhais et al. 2013), yang pada gilirannya mempengaruhi komposisi mikrobioma akar. Untuk itu diperlu biosintesis senyawa fenolik yang memobilisasi zat besi, untuk ekskresi selanjutnya ke rhizosfer (Zamioudis C, Hanson J, Pieterse CMJ, 2014), yatiu zat penghambat pertumbuhan jenis coumarin.

\section{METODE PENELITIAN}

Penelitian dilaksanakan di kebun percobaan Pusat Alih Teknologi dan Pengembangan Kawasan Pertanian Universitas Andalas, Alahan Panjang, Kabupaten Solok, Sumatera Barat, pada ketinggian tempat $1,616 \mathrm{~m}$ dpl. Kisaran curah hujan selama penelitian rata-rata $505 \mathrm{~mm}$ dengan rata-rata 15 hari hujan.

Percobaan menggunakan rancangan acak lengkap (RAL) dengan 2 faktor dan 3 ulangan. Faktor pertama adalah 4 isolat bakteri (Tanpa bakteri isolat, BT.4.1, BT.4.2, BT.4.3) dan faktor kedua adalah 4 konsentrasi coumarin $(0,50,100,150 \mathrm{mg} \mathrm{L}-1)$. Setiap kombinasi dilakukan dengan 3 kali ulangan, sehingga didapatkan 48 unit percobaan dan masing-masing unit terdiri dari 10 tanaman dengan total 480 populasi tanaman.

Media tanam yang digunakan adalah campuran tanah dan pupuk kandang (20 ton ha-1) dengan perbandingan 2: 1 (disterilkan terlebih dahulu) dan dimasukkan kedalam polibag ukuran $5 \mathrm{~kg}$. Suspensi isolat rizobakteri dengan kepadatan inokulum $10^{8}$ di aplikasikan sebanyak dua kali yaitu saat sebelum penanaman, dan pada umur 28 HST (Hari Setelah Tanam) sebanyak 10 ml dengan cara disiram di tanah sekitar perakaran tanaman kentang. Perlakuan konsentrasi coumarin dilakukan dengan cara disemprotkan pada seluruh bagian tajuk tanaman (50 ml tan-1) pada umur 28, 35, 42 HST. Benih kentang yang digunakan adalah varietas granola (G0) yang berasal dari Dieng Banjarnegara, Jawa Tengah. Benih G0 yang digunakan untuk merbanyak benih tanaman kentang yang bermutu.

Pengamatan karakterisasi morfologi rhizobakteri meliputi: bentuk koloni, elevasi koloni, tepi koloni, ukuran, warna, uji gram untuk mengetahui apakah bakteri bersifat gram positif 
(Resistensi terhadap alkali $(1 \% \mathrm{KOH})$ larut) atau negatif (Resistensi terhadap alkali $(1 \% \mathrm{KOH})$ lebih pekat) dan uji hipersensitif dengan cara menyuntikan suspensi rizobakteri indigenus secara interseluler pada jaringan permukaan bawah daun tanaman Mirabillis Jalapa dan mengamati perkembangan gejala selama 2 x 24 jam (Yanti, et.,al 2013). Pengamatan meliputi panjang akar, dan bobot akar. Data hasil pengamatan dianalisis dengan uji $\mathrm{F}$, dilanjutkan dengan uji BNJ pada taraf $5 \%$.

\section{HASIL DAN PEMBAHASAN}

\section{Panjang Akar (g)}

Hasil analisis ragam menunjukan bahwa pemberian isolat rhizobakteria dan konsentrasi coumarin berpengaruh nyata terhadap penekanan panjang akar tanaman kentang, sedangkan pengaruh isolat rhizobakteria meningkatkan panjang akar. Tabel 1 menunjukkan bahwa panjang akar terpanjang dipengaruhi oleh isolat rhizobakteria, yaitu: isolat BT.4.1 dengan tanpa konsentrasi coumarin memiliki panjang akar $63,97 \mathrm{~cm}$; isolat BT.4.2 dengan tanpa konsentrasi coumarin memiliki panjang akar $75,27 \mathrm{~cm}$; isolat BT.4.3 dengan tanpa konsentrasi coumarin memiliki panjang akar $66,30 \mathrm{~cm}$. Diduga bahwa pengaruh rhizobakteria terhadap panjang akar tanaman kentang, disebabkan karena kemampuannya untuk menghasilkan hormon tumbuh seperti asam indol asetat (IAA) yang berperan dalam memacu pertumbuhan akar, pemanjangan akar dan pengembangan akar lateral, yang membantu tanaman memperoleh air maksimal dan nutrisi.

Tabel 1. Panjang akar tanaman kentang periode 63 HST pada pemberian isolat rhizobakteria dan konsentrasi coumarin.

\begin{tabular}{|c|c|c|c|c|}
\hline \multirow{2}{*}{ Jenis Rhizobakteria } & \multicolumn{4}{|c|}{ Coumarin } \\
\hline & Tanpa & $50 \mathrm{mg} \mathrm{l}^{-1}$ & $100 \mathrm{mg} \mathrm{l}^{-1}$ & $150 \mathrm{mg}{ }^{1}$ \\
\hline \multirow{3}{*}{ Tanpa } & & -------- & --------- cn & 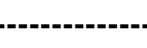 \\
\hline & 44,97 a & 58,47 a & $52,20 \mathrm{a}$ & 43,13 a \\
\hline & A & B & A & A \\
\hline \multirow{2}{*}{ BT.4.1 } & $63,97 \mathrm{~b}$ & $41,37 \mathrm{a}$ & $48,97 \mathrm{ab}$ & $43,37 \mathrm{a}$ \\
\hline & B & A & A & A \\
\hline \multirow{2}{*}{ BT.4.2 } & $75,27 \mathrm{~b}$ & $51,90 \mathrm{a}$ & $49,30 \mathrm{a}$ & 42,40 a \\
\hline & B & $\mathrm{AB}$ & A & A \\
\hline \multirow{2}{*}{ BT.4.3 } & $66,30 \mathrm{~b}$ & $47,30 \mathrm{a}$ & 43,30 a & $52,80 \mathrm{ab}$ \\
\hline & B & A & A & A \\
\hline
\end{tabular}

$\mathrm{KK}=10,40 \%$

Keterangan: * Angka-angka pada arah horizontal (baris) yang diikuti huruf kecil yang sama dan angka-angka pada arah vertikal (kolom) yang diikuti oleh huruf besar yang sama berbeda tidak nyata berdasarkan uji BNJ Taraf 5\%.

Hal yang sama juga dikemukakan oleh Tkachenko et al., (2015) dari ke empat kultivar tanaman kentang yang di inokulasi dengan rhizobakteria memiliki efek yang positif terhadap pertumbuhan panjang akar dibandingkan dengan tanaman kontrol. Menurut Deka Boruah (2003) 
bakterinisasi secara signifikan meningkatkan panjang akar dibandingkan dengan kontrol, peningkatan panjang akar berkisar dari $13 \%$ sampai $17 \%$.

Lakshmanan, Selvaraj dan Bais, (2014) menyatakan bahwa akar tanaman melepaskan beragam nutrisi organik, sehingga sinyal ini mampu menarik populasi mikroba. Sel bakteri tunggal menempel pada permukaan akar setelah pembelahan sel dan perkembangbiakan, membentuk agregat padat yang disebut sebagai macrocolonies atau biofilm (Rudrappa et al., 2008). Beberapa penelitian menyatakan bahwa pembentukan biofilm merupakan sifat esensial bagi tanaman dalam kolonisasi akar (Chen et al., 2013). Didukung oleh hipotesis Beauregard et al., (2013) pada pemeriksaan mikroskop bakteri pada akar gandum dan akar A. Thaliana, biofilm dipicu oleh berbagai sinyal yang berbeda dari satu spesies bakteri ke spesies lain. Khususnya bakteri dengan karakteristik Gram negatif (Martínez Gil et al., 2010).

Menurut Van Puyvelde et al., (2011) strain bakteri gram negatif menunjukkan respon transkripsi auksin indole-3-acetic acid (IAA), yang dihasilkan oleh bakteri dan tanaman dari efek biofilm. Diduga IAA disintesis oleh rhizobakteria dari triptofan, yang ditemukan pada konsentrasi yang berbeda pada eksudat akar menurut genotipe tanaman. Hal serupa dijelaskan oleh Jacquot et al., (2015) bahwa rhizobakteria mensintesis IAA dari triptofan dengan jalur yang berbeda, bakteri fitopatogenik menggunakan jalur indole acetamide untuk mensintesis IAA, sedangkan jalur indole piruvat acid digunakan oleh PGPR.

Selanjutnya Niro et al., (2016) menjelaskan bahwa eksudat akar juga mempengaruhi efektivitas mikroorganisme dan ketersediaan coumarin, sehingga terjadinya interaksi antara rhizobakteria dan coumarin dengan respon yang berbeda-beda. Hasil ini menunjukkan bahwa pada tingkat IAA rendah yang dihasilkan oleh rhizobakteria, coumarin dan IAA menghasilkan efek aditif terutama pada penghambatan perpanjangan akar primer dan mendorong pembentukan akar lateral. Namun, pada konsentrasi IAA tinggi yang dihasilkan oleh rhizobakteria, tidak ada efek aditif yang di amati dengan coumarin. Hal ini sesuai dengan pendapat Hossain et al., (2008) pada konsentrasi IAA rendah, coumarin dapat meningkatkan konsentrasi IAA endogen, transportasi atau sensitivitas yang mendorong aktivitasnya, sementara pada konsentrasi IAA tinggi, sinyal yang mengaktifkan pembentukan akar lateral menutupi efek aditif dari IAA dan coumarin.

Interaksi isolat rhizobakteria dan konsentrasi coumarin menunjukan penekan pada panjang akar tanaman kentang, yaitu : isolat BT.4.1 dengan konsentrasi coumarin $50 \mathrm{mg}{ }^{1}{ }^{1}, 100 \mathrm{mg}{ }^{1}{ }^{1}$, $150 \mathrm{mg} \mathrm{1} \mathrm{1',} \mathrm{memiliki} \mathrm{nilai} \mathrm{sebesar} 41,37 \mathrm{~cm}, 48,97 \mathrm{~cm}, 43,37 \mathrm{~cm}$; isolat BT.4.2 dengan konsentrasi coumarin $50 \mathrm{mg} 1^{1}, 100 \mathrm{mg} 1^{1}$, $150 \mathrm{mg}{ }^{1}{ }^{1}$, memiliki nilai sebesar 51,90 cm, 49,30 $\mathrm{cm}, 42,40 \mathrm{~cm}$; isolat BT.4.3 dengan konsentrasi coumarin $50 \mathrm{mg}{ }^{1}{ }^{1}, 100 \mathrm{mg} \mathrm{1}{ }^{1}, 150 \mathrm{mg}{ }^{1}$, memiliki nilai sebesar $47,30 \mathrm{~cm}, 43,30 \mathrm{~cm}, 52,80 \mathrm{~cm}$.

Dapat dilihat bahwa senyawa coumarin lebih efektif dalam menekan panjangan akar, tetapi mendorong pertumbuhan akar lateral (Lampiran 14). Hal ini diduga bahwa pemberian konsentrasi coumarin melalui daun dapat merangsang peningkatan konsentrasi coumarin endogen di dalam tanaman, di mana hormon coumarin endogen ditemukan menumpuk di 
jaringan akar (Kai et al., 2006). Menurut Terraza et al., (2016) efek paling nyata dari coumarin adalah menekan pertumbuhan akar, modifikasi morfologi dan histologi akar.

Hal ini sesuai dengan penelitian Lupini et al., (2014) bahwa pemberian coumarin mempengaruhi perkembangan akar pada bibit $A$. thaliana, pada konsentrasi rendah, akar primer dan akar lateral sedikit meningkat, sedangkan konsentrasi tinggi secara signifikan menghambat pertumbuhan akar primer dan meningkatkan pertumbuhan akar lateral. Penekanan pertumbuhan akar pada tanaman berkisar 70 - 90\% (Chattha et al., 2016b). Hal ini diduga dari proses stimulasi IAA yang mengakibatkan pemanjang dinding sel dan dihambat oleh senyawa coumarin endogen yang menumpuk pada akar dengan mempengaruhi metabolisme IAA yan dihasilkan oleh bakteri, dimana dalam penelitian Lupini et al., (2010) menyatakan, coumarin berinteraksi dengan jalur sinyal auksin, sehingga menyebabkan penghambatan panjang akar primer dan menstimulasi perkembangan akar lateral. Hal ini sejalan dengan pendapat Alexieva et al., (1995) senyawa coumarin mempengaruhi metabolisme IAA, dalam meningkatkan atau mengambat IAA-oksidasi didalam tanaman.

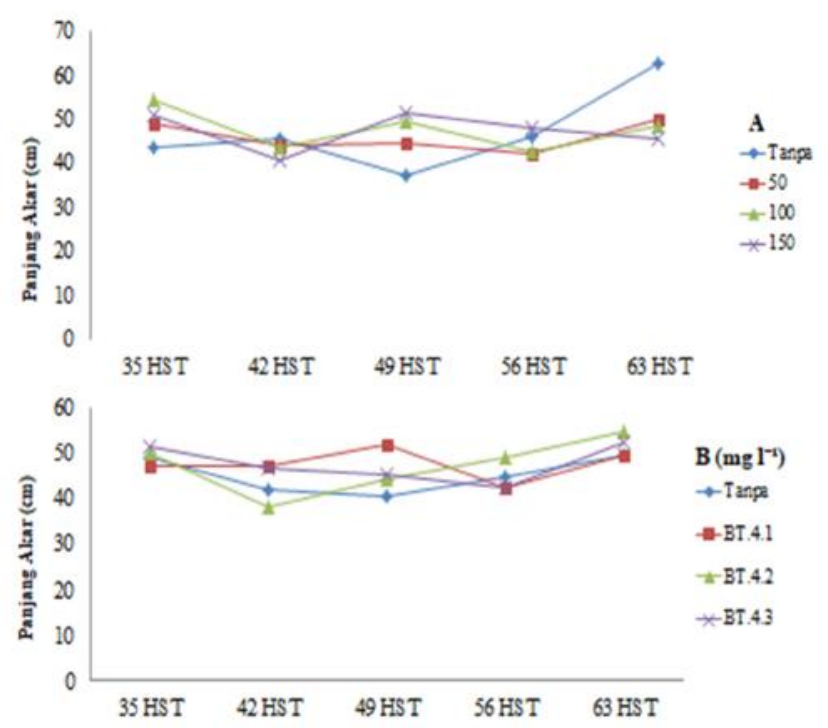

Gambar 1. Rata - rata panjang akar tanaman kentang periode 35 HST - 63 HST akibat pemberian (A) isolat rhizobakteria dan (B) konsentrasi coumarin ( $\left.\mathrm{mg} \mathrm{l}^{-1}\right)$.

Pada Gambar 1A menunjukkan peningkatan pertumbuhan panjang akar pada setiap minggunya bervariasi, hal ini disebabkan karena bakteri merupakan komponen aktif dan juga responsif terhadap perubahan kondisi lingkungan. Komposisi strain mikroba dari rizosfer ditentukan pengaruh dari berbagai faktor biotik dan abiotik. faktor biotik dan abiotik seperti jenis tanah, musim, tahap perkembangan tanaman, jarak ke akar, arsitektur akar, spesies tanaman dan kultivar dapat mempengaruhi struktur jenis mikroba dalam rhizosfer (Lakshmanan et al., 2014), tanaman dapat memilih strain bakteri dari dalam tanah dengan ekskresi eksudat akar (Huang et al., 2014). Arsitektur akar di asumsikan mempengaruhi kerapatan relatif dari mikroorganisme tanah di sekitar akar (Somers, Vanderleyden, dan Srinivisam, 2004). 
Pada Gambar 1B penekanan pertumbuhan akar disebabkan oleh perlambatan metabolisme dan menghalangi mitosis di jaringan akar yang disebabkan oleh interaksi rhizobakteri dengan tanaman inang, diduga coumarin mengganti polaritas pertumbuhan sel akar, yang berakibat menekan pemanjangan sel akar. Menurut Abenavoli et al., (2004) coumarin dapat mempengaruhi proses fisiologis dan biokimia, pada pertumbuhan akar. Di mana dalam penelitian Goodwin dan Taves (1950) menjelaskan, turunan coumarin yang paling kuat dalam menghambat pertumbuhan akar, adalah : 7,8-dihidroksi coumarin, 7,8-dihidroksi-4-methylcoumarin, 8-metil coumarin dan asam coumarin-3-karboksilat.

\section{Bobot Segar Akar (g)}

Hasil analisis ragam menunjukkan bahwa pemberian isolat rhizobakteria dan konsentrasi coumarin memberikan pengaruh terhadap bobot segar akar tanaman kentang, yaitu: Tanpa isolat rhizobakteria dengan konsentrasi coumarin $100 \mathrm{mg} 1^{1}$, $150 \mathrm{mg} 1^{1}$ memiliki nilai sebesar $25 \mathrm{~g}, 24$ $\mathrm{g}$; isolat BT.4.1 dengan konsentrasi coumarin $100 \mathrm{mg} 1^{1}$ memiliki nilai sebesar $39 \mathrm{~g}$; isolat BT.4.2 dengan konsentrasi coumarin $50 \mathrm{mg} 1^{1}, 100 \mathrm{mg} 1^{1}, 150 \mathrm{mg} 1^{1}$ memiliki nilai sebesar $27,1 \mathrm{~g}, 24 \mathrm{~g}, 20,9 \mathrm{~g}$; isolat BT.4.3 dengan konsentrasi coumarin $50 \mathrm{mg} 1^{1}$, $100 \mathrm{mg}{ }^{1}$, $150 \mathrm{mg} 1^{1}$ memiliki nilai sebesar $30,10 \mathrm{~g}, 37 \mathrm{~g}, 30 \mathrm{~g}$.

Tabel 2. Bobot segar akar tanaman kentang periode 63 HST pada pemberian isolat rhizobakteria dan konsentrasi coumarin.

\begin{tabular}{|c|c|c|c|c|}
\hline \multirow{2}{*}{ Jenis Rhizobakteria } & \multicolumn{4}{|c|}{ Coumarin } \\
\hline & Tanpa & $50 \mathrm{mg} \mathrm{l}^{-1}$ & $100 \mathrm{mg} \mathrm{l}^{-1}$ & $150 \mathrm{mg} \mathrm{l}^{-1}$ \\
\hline \multirow{3}{*}{ Tanpa } & \multicolumn{4}{|c|}{ 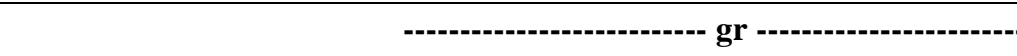 } \\
\hline & $19,03 \mathrm{a}$ & $19,00 \mathrm{a}$ & $25,00 \mathrm{~b}$ & $24,00 \mathrm{ab}$ \\
\hline & $\mathrm{AB}$ & A & A & B \\
\hline \multirow{2}{*}{ BT.4.1 } & $17,00 \mathrm{a}$ & $15,00 \mathrm{a}$ & $29,00 \mathrm{~b}$ & $11,13 \mathrm{a}$ \\
\hline & A & A & A & A \\
\hline \multirow{2}{*}{ BT.4.2 } & $24,07 \mathrm{ab}$ & $27,10 \mathrm{~b}$ & $24,00 \mathrm{ab}$ & $20,90 \mathrm{a}$ \\
\hline & $\mathrm{B}$ & B & A & B \\
\hline \multirow{2}{*}{ BT. 4.3} & $16,03 \mathrm{a}$ & $30,10 \mathrm{~b}$ & $37,00 \mathrm{c}$ & $30,00 \mathrm{~b}$ \\
\hline & A & B & B & $\mathrm{C}$ \\
\hline
\end{tabular}

$\mathrm{KK}=8,47 \%$

Keterangan: * Angka-angka pada arah horizontal (baris) yang diikuti huruf kecil yang sama dan angka-angka pada arah vertikal (kolom) yang diikuti oleh huruf besar yang sama berbeda tidak nyata berdasarkan uji BNJ Taraf $5 \%$.

Bobot segar akar yang tertinggi pada pemberian isolat BT.4.3 dengan konsentrasi coumarin $100 \mathrm{mg} \mathrm{1}$ ', yaitu: 37,00 g, sedangkan bobot segar akar terendah pada isolat BT.4.1. dengan konsentrasi coumarin $150 \mathrm{mg} 1^{1}$, yaitu: 11,13 g. Diduga pengaruh antara kedua faktor tersebut tergantung pada isolat rhizobakteria dalam mengasilkan hormon IAA dan tinggi rendahnya konsentrasi coumarin yang diberikan. Menurut Bruto et al., (2014) beberapa PGPR mampu untuk mengkolonisasi akar tanaman dan memacu pertumbuhan tanaman secara langsung melalui penghasil fitohormon seperti indole acetic acid (IAA). Menurut Naqqash et al., (2016) inokulasi rhizobakteria pada tanaman kentang menghasilkan IAA dalam jumlah yang tinggi. Sehingga 
coumarin berinteraksi dengan jalur sinyal auksin dalam menekan panjang akar dan mendorong pertumbuhan akar lateral sehingga meningkatkan bobot segar akar tanaman.

Menurut Svensson (1972) pada konsentrasi pemberian 1,5 x $10{ }^{5} \mathrm{M}$ coumarin meningkatkan lebar akar dan bobot segar akar pada tanaman gandum meskipun pertumbuhan panjang akar dihambat, namun pada konsentrasi yang lebih tinggi dari $2,5 \times 10^{-5} \mathrm{M}$ tidak mempengaruhi bobot segar akar gandum. Hal yang sama dikemukakan oleh Imanparast et al., (2013) bahwa bobot segar akar tanaman kentang meningkat pada pemberian $15 \mathrm{mg} 1^{1}$ coumarin.

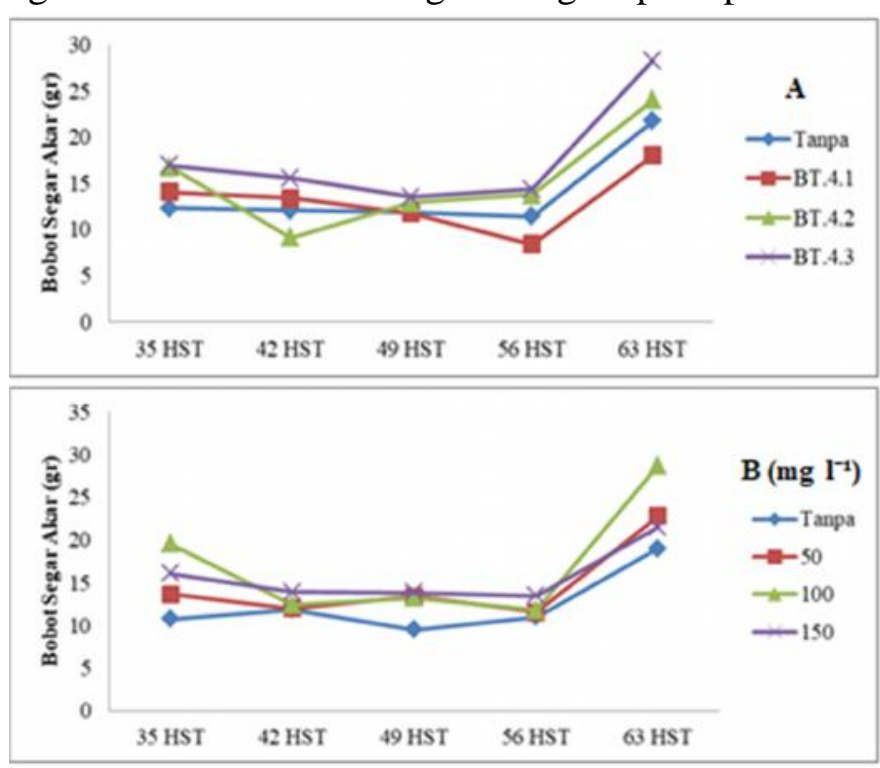

Gambar 2. Rata - rata bobot segar akar tanaman kentang periode 35 HST - 63 HST akibat pemberian (A) isolat rhizobakteria dan (B) konsentrasi coumarin ( $\left.\mathrm{mg} \mathrm{l}^{-1}\right)$.

Gambar 2A dan 2B menunjukkan peningkatan bobot segar akar pada tanaman kentang umur 56 HST. Peningkatan bobot segar dipicu oleh keberhasilan isolat rhizobakteria dalam mengkolonisasi akar tanaman merupakan langkah awal dalam memacu pertumbuhan tanaman. Lingkungan rizosfer yang dinamis dan kaya sumber energi dari senyawa organik yang dikeluarkan oleh akar tanaman merupakan habitat bagi rhizobakteria yang berperan sebagai PGPR. Asam amino dan bahan organik lainnya yang di ekresikan oleh akar tanaman kentang selanjutnya dimanfaatkan oleh tanaman dan senyawa coumarin untuk proses penghambatan pemanjangan akar, sehingga mengakibatkan akar menjadi lebar dan bobot segar akar meningkat.

Hal yang serupa juga dilaporkan oleh Sari, Warnita, \& Dwipa (2019) di mana efek coumarin menghambat panjang akar, dan mendorong perkembangan lebar akar, sehigga menyebabkan penambahan pada bobot segar akar tanaman. Chattha (2016a) menyatakan bahwa hampir seluruh senyawa coumarin pada konsentrasi 0,1 dan $0.01 \mathrm{mM}$ menyebabkan stimulasi bobot segar akar tanaman dan peningkatan bobot segar pada akar mencapai 40 - 49\%. 


\section{KESIMPULAN}

Berdasarkan hasil penelitian yang telah dilakukan dapat diperoleh kesimpulan sebagai berikut: Interaksi pemberian isolat rhizobakteria dan coumarin dapat menekan panjang akar tanaman kentang diperoleh pada isolat BT.4.1 dengan konsentrasi coumarin $50 \mathrm{mg} 1{ }^{1}$, sehingga energi yang digunakan bisa untuk pembentukan biji. Sedangkan pemberian coumarin secara tunggal tidak mempengaruhi, tetapi coumarin dapat menekan panjangan akar dan bobot basah akar.

\section{REFERENSI}

Abenavoli, M.R.., A. Sorgonà, S. Albano and G. Cacco. 2004. Coumarin differentially affects the morphology of different root types of maize seedlings. Journal of Chemical Ecology. 30:1871-83.

Beauregard, P.B., Y. Chai, H. Vlamakis, R. Losick and R. Kolter. 2013. Bacillus subtilis biofilm induction by plant polysaccharides. Proceedings of the National Academy of Sciences, 110 (17), E1621-E1630.

Bruto, M., C. Prigent-Combaret, D. Muller and Y. Moenne-Loccoz. 2014. Analysis of genes contributing to plant-beneficial functions in Plant Growth-Promoting Rhizobacteria and related Proteobacteria. Scientific Reports, 4, p. 6261.

Carvalhais, Lilia C., Paul G. Dennis, Dayakar V. Badri, Gene W. Tyson, Jorge M. Vivanco, and Peer M. Schenk. 2013. "Activation of the Jasmonic Acid Plant Defence Pathway Alters the Composition of Rhizosphere Bacterial Communities." PLOS ONE 8(2):1-5.

Chattha, F.A, M. Nisa, M.A. Munawer and S. Kousar. 2016a. Coumarin Based Heteroaromatics as Plant Growth Regulators. University of the Punjab, Pakistan. DOI: 10.5772/64854.

Chattha, F.A, M. Nisa, M.A. Munawer and S. Kousar. 2016b. 2-Methylquinolin-4(1H)-on-3acetic acids as Inhibitors of seed germination and early growth of seedlings. International Journal of Agronomy and Agricultural Research (IJAAR) Vol. 9, No. 4, p. 9-15. ISSN: 2223-7054.

Chen, Y., F. Yan, Y. Chai, H. Liu, R. Kolter. and R. Losick.. 2013. Biocontrol of tomato wilt disease by Bacillus subtilis isolates from natural environments depends on conserved genes mediating biofilm formation. Environmental Microbiology, 15(3), 848-864.

Deka Boruah, H., B. Rabha, N. Saikia and B.S. Kumar. 2003. Fluorescent Pseudomonas influences palisade mesophyll development and spatial root development in Phaseolus vulgaris. Plant and Soil 256: 291-301, 2003.

Fageria. N. K. 2013. The Role of Plant Roots in Crop Production. CRC Press, New York.

Gahoonia, T. S. and N. E. Nielsen. 2004. Root traits as tools for creating phosphorus efficient crop varieties. Plant Soil 260:47-57.. 
Goodwin, R. H and C. Taves. 1950. The effect of coumarin derivatives on the growth of Avena roots. Amer. Journ. Bot., 3"1: 224-23.

Hossain, M., J. Li, S. Guo and M. Fujit. 2008. Suppressive Effects of Coumarins on Pumpkin Seedling Growth and Glutathione S-Transferase Activity. Journal of Crop Science and Biotechnology. Vol 11 (3) : 187-192.

Huang, X. F., J.M. Chaparro, K.F. Reardon, R. Zhang, Q. Shen and J.M. Vivanco. 2014. Rhizosphere interactions: root exudates, microbes, and microbial communities. Canadian Journal of Botany, 92, 267-275.

Imanparast, F., A. Tobeh, A. Gholipouri, D. Hassanpanah and L. Imanparast. 2013. Coumarin and Jasmonic acid interaction and main effectson twopotato mini-tubers cultivars yield, and yield components gradation. International Journal of Agriculture and Crop Sciences (IJACS). Vol., 5 (16), 1800-1812.

Jacquot, J.P and P. Gadal. 2015. Advances In Botanical Research Plant Microbe Interactions. London. Elsevier. ISBN: 978-0-12-420116-3.

Kai, K., B. Shimizu, M. Mizutani, K. Watanabe and K. Sakata. 2006. Accumulation of coumarins in Arabidopsis thaliana. Phytochemistry. Vol. 67:379-86.

Kecskés, M. L., A. T. M. A. Choudhury, A. V. Casteriano, R. Deaker, R. J. Roughley, L. Lewin, R. Ford, and I. R. Kennedy. 2016. "Effects of Bacterial Inoculant Biofertilizers on Growth, Yield and Nutrition of Rice Australia." Journal of Plant Nutrition 39(3):377-88.

Kumar, Vijay and Nivedita Sharma. 2017. "Plant Growth Promoting Rhizobacteria as Growth Promoters for Wheat : A Review." Agricultural Research \& Technology 12(4).

Lakshmanan, V., G. Selvaraj and H.P. Bais. 2014. Functional soil microbiome: belowground solutions to an aboveground problem. Plant Physiology, 166, 689-700.

Lupini, A., A. Sorgonà, Anthony, J. Miller and M.R. Abenavoli. 2010. Short-term effects of coumarin along the maize primary root axis. Plant Signaling and Behavior 5:11, 13951400 .

Lupini, A., F. Araniti, F. Sunseri and M.R. Abenavoli. 2014. Coumarin interacts with auxin polar transport to modify root system architecture in Arabidopsis thaliana. Plant Growth Regul. Springer Science. DOI 10.1007/s10725-014-9893-0.

Majeed, Afshan, M. Kaleem Abbasi, Sohail Hameed, Asma Imran, and Nasir Rahim. 2015. "Isolation and Characterization of Plant Growth-Promoting Rhizobacteria from Wheat Rhizosphere and Their Effect on Plant Growth Promotion." Frontiers in Microbiology 6(198):1-10.

Martínez-Gil, M., F. Yousef-Coronado and M. Espinosa-Urgel. 2010. LapF, the second largest Pseudomonas putida protein, contributes to plant root colonization and determines biofilm architecture. Molecular Microbiology, 77, 549-561. 
Naqqash, T., S. Hameed, A. Imran, M.K. Hanif, A. Majeed and J. Elsas. 2016. Differential Response of Potato Toward Inoculation with Taxonomically Diverse Plant Growth Promoting Rhizobacteria. Frontiers in Plant Science. 7: 144.

Niro, E., R. Marzaioli, S. Crescenzo, B. Abrosca, S. Castaldi, A. Esposito, A. Fiorentino and F. Rutigliano. 2016. Effects of the allelochemical coumarin on plants and soil microbial community. Soil Biology and Biochemistry. 95. 30-39.

Noulas, Christos, Markus Liedgens, Peter Stamp, Ioannis Alexiou, and Juan M. Herrera. 2010. "Subsoil Root Growth of Field Grown Spring Wheat Genotypes (Triticum Aestivum L.) Differing in Nitrogen Use Efficiency Parameters." Journal of Plant Nutrition 33(13):18871903.

Parnell, J. Jacob, Randy Berka, Hugh A. Young, Joseph M. Sturino, Yaowei Kang, D. M. Barnhart, and Matthew V. Dileo. 2016. "From the Lab to the Farm: An Industrial Perspective of Plant Beneficial Microorganisms." Frontiers in Plant Science 7(AUG2016):1-12.

Rudrappa, T., K.J. Czymmek, P.W. Paré and H.P. Bais. 2008. Root-secreted malic acid recruits beneficial soil bacteria. Plant Physiology, 148, 1547-1556.

Sari, Henny Puspita, Warnita Warnita, and Dan Indra Dwipa. 2019. "Pemberian Rizobakteri Dan Coumarin Pada Pertumbuhan Dan Pembentukan Umbi Tanaman Kentang (Solanum Tuberosum L)." Jurnal Agronomi Indonesia (Indonesian Journal of Agronomy) 47(2):18895.

Svensson, S.B. 1972. The effect of coumarin on root growth and root histology. Physiol Plantar. 24:446-70.

Terraza, P., A. Villarroya, P. Fourcroy, J. Briat, A. Abadía, F. Gaymard, J. Abadía and A. Fernández. 2016. Accumulation and Secretion of Coumarinolignans and other Coumarins in Arabidopsis thaliana Roots in Response to Iron Deficiency at High pH. Front. Plant Sci. $7: 1711$

Tkachenko, O., N. Evseeva,N. Boikova, L. Matora, Burygin, Y. Lobachev and S. Shchyogolev. 2015. Improved potato microclonal reproduction with the plant growth-promoting rhizobacteria Azospirillum. Agronomy for Sustainable Development. Volume 35, Issue 3, pp 1167-1174.

Van Puyvelde, S., L. Cloots, K. Engelen, F. Das, K. Marchal and J. Vanderleyden. 2011. Transcrip to meanalysis of the rhizosphere bacterium Azospirillum brasilen sereveals an extensive auxin response. Microbial Ecology, 61(4), 723-728.

Ziegler, Jörg, Stephan Schmidt, Ranju Chutia, Jens Müller, Christoph Böttcher, Nadine Strehmel, Dierk Scheel, and Steffen Abel. 2016. "Non-Targeted Profiling of Semi-Polar Metabolites in Arabidopsis Root Exudates Uncovers a Role for Coumarin Secretion and Lignification during the Local Response to Phosphate Limitation." Journal of Experimental Botany 67(5):1421-32. 